\title{
TERRITORIAL ORGANIZATION OF RESTAURANT FACILITIES AS A PART OF THE SOCIAL SPHERE WITHIN AGGLOMERATIVE RESETTLEMENT SYSTEMS
}

\author{
Kateryna DMYTRIIEVA \\ Taras Shevchenko National University of Kyiv, Ukraine \\ k.dmytriieva@gmail.com
}

\begin{abstract}
The article is devoted to the problems of functioning of restaurant facilities as a part of both social sphere and commercial sector equally within the large settlements. Attention to the factors of the restaurant industry generally has been paid, and the success factors of individual institutions have been stressed. Some aspects and differences of the closed restaurant business network and public network type have been analyzed. Problems of law regulation of the industry have been outlined. The dynamic of development of the industry and its relationship with the economic background of the country has been demonstrated. System of elements of the territorial organization of restaurants in the metropolitan area has been proposed. Items considered in the paper are illustrated by examples of Kyiv agglomeration restaurants. The article visualized with the graphics, tables and charts.
\end{abstract}

Key words: restaurant facilities, territorial organization, social sphere, settlement system

UDC: 911.3

\section{ТЕРИТОРІАЛЬНА ОРГАНІЗАЦІЯ РЕСТОРАННОГО ГОСПОДАРСТВА ЯК СКЛАДОВОЇ СОЦІАЛЬНОї СФЕРИ В АГЛОМЕРАТИВНИХ СИСТЕМАХ РОЗСЕЛЕННЯ}

\author{
Катерина ДМИТРІєВА \\ Київський начіональний університет імені Тараса Шевченка, Україна \\ k.dmytriieva@gmail.com
}

\begin{abstract}
Анотація: Стаття присвячена проблемам функціонування ресторанного господарства як складової соціальної сфери і, водночас, комерційної сфери у рамках великих поселень. Приділена увага факторам розвитку ресторанного господарства в цілому, а також виокремлені чинники успішності окремих закладів. Проаналізовані окремі аспекти та відмінності розвитку закритої мережі ресторанного господарства та мережі загальнодоступного типу. Окреслені проблеми законодавчого регулювання у галузі. Продемонстрована динамічність розвитку галузі, її взаємозв'язок з економічним фоном країни. Запропонована система складових елементів територіальної організації ресторанного господарства агломерації. Питання, що розглядаються у статті, ілюструються прикладами ресторанного господарства Київської агломерації. Стаття унаочнена
\end{abstract}

(С) К. Дмитрієва 
графічними матеріалами, таблицями та схемами.

Ключові слова: ресторанне господарство, територіальна організація, соціальна сфера, системи розселення

удк: 911.3

Вступ. Постановка проблеми. Місто як особлива одиниця системи розселення $є$ ареною прояву та впровадження новітніх тенденцій будь-якої господарської діяльності, у тому числі ресторанного господарства. Рівень розвитку соціальної сфери та соціальної інфраструктури є показником якості людського капіталу, тому їх розвиток $є$ фундаментом ефективності людських ресурсів міста.

Дослідження ресторанного господарства як складної та багатоаспектної галузі, яка має певні протиріччя територіальної організації в залежності від форм господарської діяльності найбільш комплексно проявляється та досліджується на рівні великого міста чи агломераційного утворення.

Аналіз останніх досліджень і публікацій. Питання стану соціальної сфери досліджували О. Любіцева, М. Мальська, В. Юрківський, питання функціонування сфери ресторанного господарства В. Архипов, В. Дорошенко, В. Карсекін, Г. П'ятницька, П. Черномаз та інші.

Постановка завдання. Розуміння ролі ресторанного господарства та особливостей його територіальної організації i функціонування в рамках великого міста дає змогу більш ефективно відповідати на потреби населення та регулювати діяльність галузі.

Стаття призначена для:

- уточнення ролі ресторанного господарства у складі сфери послуг;

- визначення особливостей функціонування ресторанного господарства у складі великого компактного поселення;

- виявлення факторів та передумов функціонування галузі;

- структурування елементів територіальної організації ресторанного господарства локальної системи розселення.

Виклад основного матеріалу. За Куценко В. I. до соціальної сфери прийнято відносити види діяльності, що визначають стійкий розвиток регіону i безпосередньо досягнення генеральної мети підвищення якості життя населення регіону. Такими сферами діяльності є: охорона здоров'я, житловокомунальна сфера, освіта, наука, культура, фізична культура і спорт, транспортне, інформаційне, торгове, побутове обслуговування [5].

Царук I. 3 посиланням на Куценко В. I. та Остафійчука Я. В. розглядає соціальну сферу як сферу діяльності людей, результатом якої є послуги, що задовольняють потреби суспільства й окремих його членів і пов'язані зі створенням доданої вартості [5].

Роль ресторанного господарства у складі сфери послуг полягає першочергово у задоволенні фізичних потреб людей, проте не варто ігнорувати духовний аспект - знайомство з іншими культурами через національну кухню, комунікативні аспекти дозвілля, отримання нових вражень завдяки концептуальним закладам.

Центр перспективних соціальних досліджень Міністерства соціальної політики України визначає поняття «соціальна інфраструктура» як стійку сукупність матеріально-речових елементів, які створюють умови для задоволення всього комплексу потреб з метою відтворення людини і суспільства. Значення соціальної інфраструктури полягає у тому, що вона $\epsilon$ ареною взаємодії матеріально-речового середовища і соціальних суб'єктів та забезпечує умови для раціональної організації їхнього життя i діяльності. За своєю внутрішньою організацією інфраструктура соціальної сфери $є$ системою закладів, установ, підприємств і органів управління, які забезпечують ефективність функціонування усіх інститутів соціальної сфери. Соціальна інфраструктура є гарантією задоволення базових життєвих потреб людини як у повсякденному житті, так і у кризових ситуаціях.

Соціальна інфраструктура може характеризуватися кількістю установ, організацій, які забезпечують процеси створення, медичного, побутового i транспортного обслуговування, а також кількістю місць у них, обсягом надання соціальних послуг [4].

Ресторанне господарство як складову соціальної інфраструктури зазвичай найдоцільніше оцінювати за подібними показниками - кількість закладів, кількість посадкових місць. Обсяг наданих послуг можливо оцінити через товарооборот закладу.

Розгляд ресторанного господарства у рамках локальних систем розселення $є$ найбільш логічним, оскільки основні потреби у даних послугах прямо залежать від кількості споживачів, що сконцентровані у найбільших населених пунктах місцях зосередження і притягання населення.

За результатами попередніх досліджень, найвищого рівня розвитку ресторанне господарство набуло саме у міських агломераціях - компактному територіальному розміщенні міських населених пунктів, об'єднаних інтенсивними господарськими, трудовими і культурно-побутовими зв'язками [11].

На основі локальних систем розселення формуються локальні системи послуг - відповідно до їх історичних, економічних, ресурсних, соціальних особливостей. Локальні системи послуг найчастіше систематизують і вивчають ієрархічно.

На думку Мальської, у локальних системах розселення створюються соціально-економічні умови життєдіяльності населення за рівного доступу до матеріальних та культурних благ незалежно від місця проживання [7, 92].

Риси ресторанного господарства агломеративних утворень України досить схожі, оскільки історично розвиток споживання у галузі був підпорядкований спільним рисам i закономірностям розвитку 
господарства України.

Варто відзначити, що функціонування закладів соціальної сфери у рамках міських утворень 3 одного боку, перебуває у пріоритетному порівняно 3 сільською місцевістю становищі - як через кількісні, так і через якісні показники, та не варто забувати, що навантаження на соціальну інфраструктуру міста у зв'язку з міграційними потоками в місто зростає набагато швидке, отже, швидке реагування на виклики мешканців є завданням органів управління будь-якого міста.

Варто звернути увагу, що при оцінці потреб споживачів необхідно орієнтуватися не лише на тип території (сільська/міська), а й прагнути до певних показників в залежності від розміру міста. Зокрема, рекомендована різна кількість посадкових місць, що здатні задовольнити суспільні потреби, у місті 3 чисельністю населення до 50 тис осіб та містоммільйонером відрізняється у 2,5 рази. (див. табл. 1.)
Важливою проблемою соціального комплексу України загалом є дуже застарілий стан соціальної інфраструктури у всіх ¥iі проявах. Порівняно 3 іншими сферами (медицина, культура), ресторанне господарство має набагато кращі показники, оскільки високо комерціалізоване. Сумна доля переважно спіткає заклади закритої мережі.

Мережа ресторанного господарства закритого типу - це заклади, призначені для окремої групи населення. Зазвичай воно призначене для пільгових категорій громадян та/або є максимально доступним по ціні. Наприклад, це безоплатне харчування для дітей-учнів 1-4 класів загальноосвітніх навчальних закладів, дітей пільгових категорій в випадках, передбачених законодавством України (діти-сироти i діти, позбавлені батьківського піклування, які перебувають під опікою і виховуються в сім'ях; діти, потерпілі від наслідків аварії на Чорнобильській AEC; діти працівників органів внутрішніх справ,

Таблиия 1

Орієнтовні нормативи розвитку мережі ресторанного господарства в Україні, місць у закладах ресторанного господарства у розрахунку на 1 тис осіб [10]

\begin{tabular}{|c|c|c|}
\hline Контингент населення & $\begin{array}{c}\text { Норматив місць } \\
\text { (другий етап } \\
\text { розвитку) }\end{array}$ & $\begin{array}{c}\text { Допустимий мінімум місць у закладах РГ } \\
\text { підприємств-юридичних осіб та фізичних } \\
\text { осіб-підприємців (перший етап розвитку) }\end{array}$ \\
\hline $\begin{array}{c}\text { Населення міст з чисельністю, тис осіб: } \\
\text { до 50,0 }\end{array}$ & 34 & 25 \\
\hline від 50,1 до 100,0 & 39 & 35 \\
\hline від 100,1 до 250,0 & 45 & 40 \\
\hline від 250,1 до 500,0 & 52 & 53 \\
\hline від 500,1 до 1000,0 & 60 & 61 \\
\hline понад 1000,0 & 75 & 250 \\
\hline Населення сільських населених пунктів & $15(20)$ & 200 \\
\hline Зосереджені колективи працюючих & 330 & 330 \\
\hline Працюючі в установах, організаціях & 200 & 500 \\
\hline Учні ЗНЗ та ПТН3 & 330 & 180 \\
\hline Учні шкіл-інтернатів & 500 & \\
\hline Студенти ВН3 & 200 & \\
\hline
\end{tabular}

Таблиия 2

Вартість харчування учнів загальноосвітніх навчальних закладів м. Києва у 2014 р [3]

\begin{tabular}{|l|c|c|c|}
\hline Район & $\begin{array}{c}\text { Bартість гарячого } \\
\text { обіду для учнів 1-4 } \\
\text { класів, грн. }\end{array}$ & $\begin{array}{c}\text { Вартість гарячого } \\
\text { обіду для учнів 5-11 } \\
\text { класів пільгових } \\
\text { категорій, грн. }\end{array}$ & $\begin{array}{c}\text { Вартість дістичного } \\
\text { харчування для учнів 5- } \\
11 \text { класів, грн. }\end{array}$ \\
\hline Голосіївський & 7,20 & 7,54 & 7,54 \\
\hline Дарницький & 7,50 & 8,50 & 8,50 \\
\hline Деснянський & 7,30 & 7,80 & 7,80 \\
\hline Дніпровський & 7,10 & 8,15 & 8,15 \\
\hline Оболонський & 7,35 & 8,90 & 8,90 \\
\hline Печерський & 7,35 & 8,05 & 8,05 \\
\hline Подільський & 7,00 & 8,14 & 8,14 \\
\hline Святошинський & 7,00 & 7,70 & 7,70 \\
\hline Солом'янський & 7,00 & 8,10 & 8,10 \\
\hline ШІевченківський & 6,50 & 7,00 & 7,00 \\
\hline Середня вартість & 7,13 & 7,99 & 7,99 \\
\hline помісту: & & & \\
\hline
\end{tabular}


які загинули при виконанні службових обов'язків, дітей, батьки яких загинули під час участі в антитерористичній операції тощо).

Проте навіть у Києві харчування дітей 1-4 класів можуть трансформувати з безкоштовного на оплачуване батьками (8-10 грн).

Харчування у медичних закладах регулюється Наказом MO3 «Про удосконалення лікувального харчування та роботи дієтологічної системи в Україні» від 29.10.2013 р № 931 та визначає харчування як частину лікувального процесу. Контроль за його дотриманням покладається на Головного лікаря медичного закладу. Передбачається чотириразовий режим харчування 3 дотриманням рекомендацій в залежності від типу захворювання [9].

У санаторно-курортних закладах пропонується 5 універсальних раціонів харчування. Основний принцип такого дієтичного харчування збалансованість хімічного складу раціонів 3 урахуванням біологічних ефектів харчових речовин та окремих продуктів при різних патологіях [6].

Соціальний ефект, який має бути досягнутий завдяки закладам закритої мережі - це турбота про збалансоване та здорове харчування населення.

Натомість, заклади загальнодоступної мережі характеризуються різноманіттям форм організації, форматів та концепцій. Варто зауважити, що певні новітні тренди цікавих закладів, що виникають спонтанно, можуть стикатися 3 юридичними складнощами функціонування. Наприклад, проведення фестивалю Ресторанний день (одночасне відкриття закладів ресторанного господарства аматорами на один день у громадських місцях парках, скверах тощо 3 метою відчути специфіку роботи та в галузі та отримати новий досвід) стикається 3 неможливістю отримати оплату за вкладені ресурси - лише у вигляді чайових, а також, теоретично - проблемами санітарного регулювання, оренди місця тощо.

Хоча зміни у регулюючих документах мають місце, вони часто спричинені і впроваджуються лише після трагічних подій. Наприклад, використання газових балонів у мобільних кав'ярнях було заборонене лише після вибуху однієї з них.

Одним з дужепроблемних питань для агломерації $€$ функціонування закладів вуличної їжі. 3 одного боку, протягом останніх років у сегменті вуличної їжі з'явились заклади, які за якістю страв та їх смаковими характеристиками близькі до кафе середнього цінового сегменту, але готуються максимально швидко. Вони здатні задовольнити спонтанні потреби у послугах харчування, а для офісного центру міста i його працівників також є альтернативою в плані урізноманітнення меню для щоденного харчування. Проте неврегульованість питань розміщення таких закладів, зокрема, у МАФах, $є$ не менш болючих питанням урбаністичного розвитку.

Ряд проблем підприємництва у ресторанному господарстві $є$ спільним та типовим для ведення господарської діяльності взагалі - надзвичайно високі показники оренди, кваліфікація персоналу тощо.
Питання рівних умов просторової доступності $\epsilon$ ключовим та наскрізним щодо усіх галузей соціальної сфери. У ресторанному господарстві воно повинно розкриватися через виявлення і задоволення ключових точок потреби (в першу чергу, сталої навчальні заклади, зони ділової активності міста, туристичні зони тощо). 3 іншого боку, завдяки розумному маркетингу окремі заклади можуть провокувати виникнення споживчої потреби у зонах, які не є типовими для галузі загалом.

Окремого підходу при вивченні потребують заклади ресторанного господарства, що виконують стабільне соиіальне навантаження - їдальні при навчальних закладах, лікувальних закладах та підприємствах. Це виражається в їх територіальній прив'язці до основних об'єктів, комплексності меню, ціновій політиці тощо.

Основою територіальної організації соціальної сфери агломерації має бути розуміння потреб населення та специціки надання послуг. Окрім того, наповненість кожної підгалузі підприємствами різної форми власності часто може бути підпорядковане різним ринковим законам, та глобально слугуючи одній цілі, працювати за різними правилами. Водночас інтереси малого підприємництва та великих закладів-мереж можуть не перетинатися, а взаємодоповнюватись, заповнюючи вільні ринкові ніші.

Факторами, що визначають доцільність i масштаби функціонування галузі ресторанного господарства у складі сфери послуг міста, i перспективи розвитку закладів є:

- Населення - зокрема, його чисельність, статево-вікова структура, професійний склад.

До цього блоку показників можна віднести також міграційні потоки (внутрішній напрям село-місто, маятникову міграцію в межах локальних систем розселення).

- Економічні фактори - загальний рівень розвитку економіки міста, рівень доходів населення, що визначає купівельну спроможність,

Сюди ж можна віднести існуючий стан розвитку ресторанного господарства міста, стан підприємництва загалом, у т.ч. малого.

- Iнфраструктура-впершучергу,транспортна, а також об'єкти, до якої заклади ресторанного господарства можуть бути «супровідними» навчальні заклади усіх типів, туристичні об'єкти, торговельні центри, об'єкти культури тощо.

- $\quad$ Психологічні фактори - культура та традиції споживання їжі поза домом.

Супровідні ресурси та послуги конкретних закладів є важливою причиною первинного вибору місця відвідування. Це дуже стосується питань:

- транспортної інфраструктури - місця для паркування, наявності пандусів для людей 3 особливими потребами.

- фінансової інфраструктури - можливості розрахунку карткою.

- надання торговельних послуг - вони мають цікавити споживача і органічно вливатися в тематику закладу, наприклад, продаж кави в зернах, книжок, 
тематичних сувенірів.

- сировинної бази - цікаво, що в радянський період стан сільського господарства регіону визначався як один з факторів розвитку ресторанного господарства. 3 переходом до ринкової економіки він явно відійшов на другий план, а пізніше трансформувався досить несподіваним чином - у елітному сегменті. Зокрема, підприємства елітного рівня та вегетаріанські заклади досить часто прагнуть співпрацювати 3 конкретними фермерськими господарствами з метою контролю якості продукції.

- додаткових послуг, зокрема, розважальних, конференц - послуг, фото послуг, допоміжного персоналу (наприклад, няні) у закладі тощо, а також відкритість до діалогу та бажання співпрацювати закладу ресторанного господарства при наданні цих послуг.

- соціальних ініціатив закладу (можливість «підвісити» каву - оплатити наперед напій для будького, хто його захоче отримати), благодійні акції («День Щастя в МакДональдз») тощо.

Варто зупинитися на тому, що галузь ресторанного господарства $\epsilon$ чудовим індикатором економічного фону держави взагалі.

Зокрема, аналіз обсягу роздрібного товарообороту та кількості закладів міста Києва чітко відбиває річний лаг прояву кризи 2008 р, а також, очевидно - 2013 р (див. рис 1).
Заклади ресторанного господарства дають можливість збагатити та урізноманітнити міський простір, а також альтернативно використовувати нетипові міські ділянки. Чудовим прикладом роботи 3 простором є проведення фестивалів вуличної їжі на парковці ринку «Даринок» (арт-завод «Платформа») та ВДНГ. Оскільки пошук потрібного приміщення болючетапроблематичнепитання, варто замислитись над реформацією промислових занедбаних об'єктів та ідеї багатофункціональності закладів ресторанного господарства.

На нашу думку, система територіальної організації ресторанного господарства локальної територіальної системи розселення складається 3 наступних елементів (див. рис. 2):

\section{Стаиіонарні форми:}

- точкові елементи - окремі поодинокі заклади ресторанного господарства - кафе, бари, ресторани;

- $\quad$ вузлові елементи - компактні скупчення 5 i більше закладів, наприклад, фуд-корти;

- лінійні елементи - ланцюги закладів, що переважно приурочені до центральних та туристичних вулиць міста, зон біля транспортних зупинок тощо.

\section{Тимчасові форми:}

- точкові елементи - поодинокі заклади, функціонування яких пов'язане 3 складнощами юридичного регулювання їх розміщення (мобільні

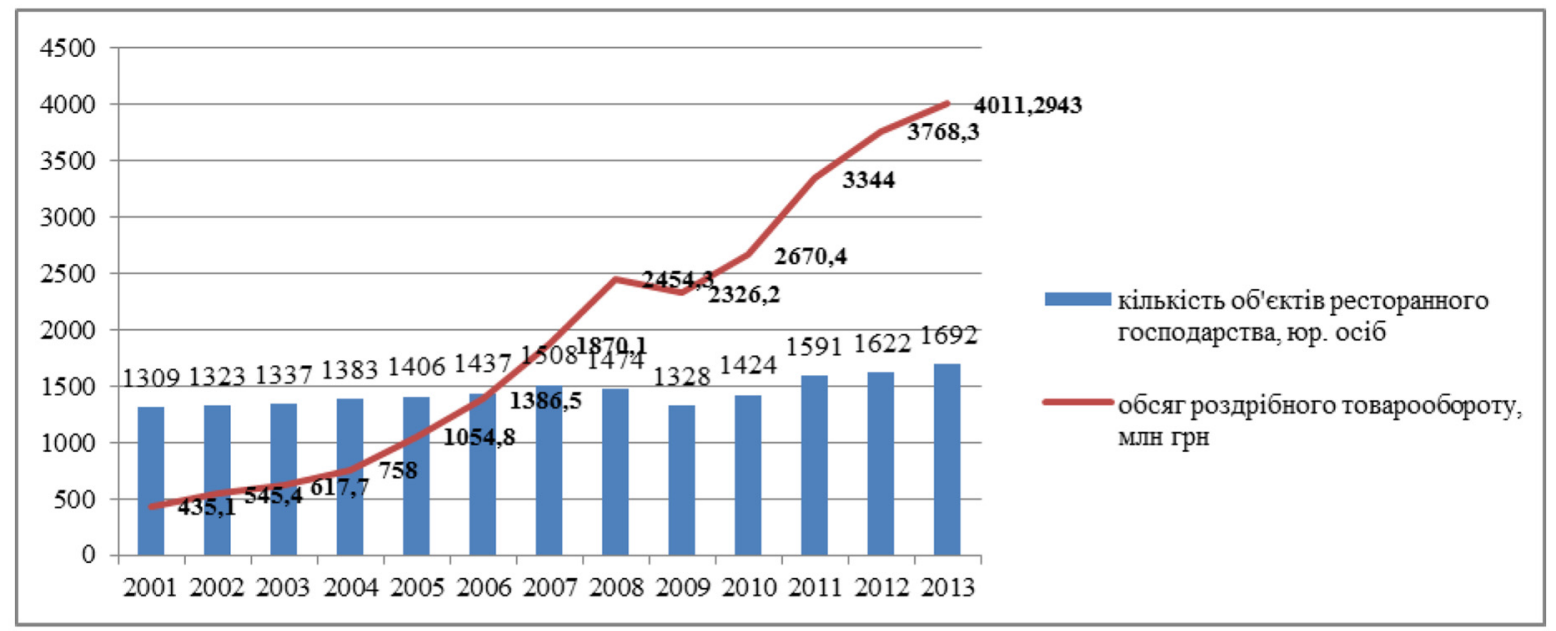

Рис. 1. Динаміка кількості закладів та обсягу роздрібного товарообороту ресторанного господарства м. Києва, 2001 - 2013 рр. [складено за матеріалами 2]
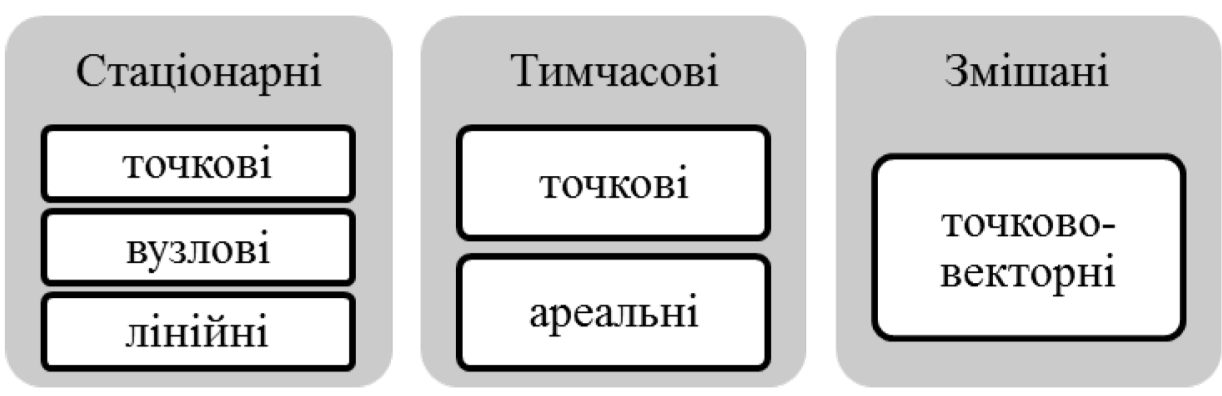

Рис. 2. Складові елементи (форми) територіальної організації ресторанного господарства локальної територіальної системи розселення, складено автором. 
кав’ярні, пересувні фургони);

- ареальні - періодичні скупчення закладів при проведенні фестивалів вуличної їжі, святкових ярмарків тощо.

\section{Змішані форми:}

- точково-векторні елементи - наприклад, служби кейтерингу, виїзні служби доставки їжі - виготовлення їжі відбувається стаціонарно, споживання - в змінній точці попиту.

Київська агломерація як транспортний, господарський, освітній, туристичний, фінансоводіловий центр країни закономірно має найвищий рівень розвитку ресторанного господарства в Україні. Офіційна статистика станом на початок 2014 р нараховує у м. Київ 1692 юридичних осіб - об'єктів ресторанного господарства. У Київській області 808. [8, 106] Кількість фізичних-осіб підприємців за авторською оцінкою може досягати 2-4 тис.

Розглядаючи Київську агломерацію, можна навести такі приклади кожного 3 елементів територіальної організації ресторанного господарства.

\section{Стаціонарні:}

- точкові - паб «Чорне Порося», ресторан «Культ Ра»;

- вузлові - фудкорти ТЦ «Караван», ТЦ «Глобус», «Ocean Plaza»;
- лінійні - заклади Русанівської набережної (фан-бар «Банка», кафе «Жовток», паста-бар «Spaghetti», ресторан «Tarantino Italian\&Grill», сушібар «Муракамі», піццерія «Челентано»; заклади вуличної їжі біля м. Контрактова площа.

Тимчасові:

- точкові - мобільні кав'ярні різних ТМ;

- ареальні - фестиваль вуличної їжі на артзаводі «Платформа» (м. Даринок.

\section{Змішані:}

- точково-векторні - служби замовлення їжі «The Burger», «Ping Pong».

Висновки. Локальна система розселення зазвичай базується на добре сформованому господарському комплексі. Наявність великої кількості споживачів дозволяє, відносно рівномірно розмістивши заклади, задовольнити їх потреби, до того ж вимагає постійного підвищення якості та різноманіття надання послуг. Передумовами розвитку ресторанного господарства у локальних системах розселення є фактори, зумовлені характеристиками населення, економічною стадією розвитку території та iï інфраструктурними особливостями, а також культурно-психологічні фактори. Територіальна організація ресторанного господарства локальної системи розселення представлена тимчасовими та стаціонарними елементами різних масштабів.

\section{References:}

1. Caruk Ì. M. Teoretičnì pìdhodi ŝodo viznačennâ socìal'noï sferi âk skladovoï ekonomìki ta ïi funkcìj [Theoretical approaches to the definition of the social sphere as a part of the economy and its functions]. Ekonomika. Upravlinnâ. İnnovaciï [Economy. Management. Innovation]. Vol. 1, 2009. Available at website: http://nbuv.gov.ua (in Ukrainian).

2. Golovne upravlinnâ Deržavnoï službi statistiki Ukraïni u m. Kiêvì [Main Department of State Statistics Service of Ukraine in Kyiv] - Available at: http://www.kiev.ukrstat.gov.ua/

3. Harčuvannâ u navčal'nih zakladah. Departament osviti ì nauki, molodì ta sportu vikonavčogo organu Kïvs'koï mis'kö̈radi (KMDA). [Nutrition in schools. Department of Education, Youth and Sports of the Kyiv Municipal Council] - Available at: http://don.kievcity.gov.ua/content/harchuvannya-u-navchalnyh-zakladah.html (In Ukrainian).

4. Ìl'čuk L. İ. Deržavne upravlìnnâ socìal'nô̂ sferoû v Ukraïnì. Centr perspektivnih social'nih doslidžen' Mììsterstva social'noï politiki Ukrä̈ni ta NAN Ukrä̈ni. [Public administration of social sphere in Ukraine. Center of perspective social researches of the Ministry of social policy of Ukraine and NSA of Ukraine]. Available at website: http://www.cpsr.org.ua (In Ukrainian).

5. Kucenko V. Ì. Social'na sfera: real'nìst' i konturi majbutn'ogo (pitannâ teorï ì praktiki): Monografiâ. [Social sphere: reality and outlines of the future (questions of theory and practice): Monograph]. Nizhyn, 2008, 818 p. Available at: http://www.rvps.kiev.ua/PUBLIK/Mono58.html (In Ukrainian).

6. Likuval'ne harčuvannâ v sanatorno-kurortnih zakladah. Kurorti ta sanatorï Ukraïni. [Therapeutic nutrition in spa resort facilities. Resorts and spa facilities of Ukraine]. Available at: http://sanikur.com/uk/4/22/29/ (In Ukrainian).

7. Mal's'ka M. P. Prostorovi sistemi poslug (teoriâ, metodologîa, praktika): Monografiâ. [ Spatial systems of services (theory, methodology, practice): Monograph.] Kyiv, 2009, 363 p.

8. Mereža rozdrìbnoï torgìvlì ta restorannogo gospodarstva pìdpriêmstv na 1 sìcnâ 2014 roku [Retail trade network and restaurants enterprises for January 1, 2014]. Available at: http://www.ukrstat.gov.ua/ (In Ukrainian).

9. Nakaz MOZ vid 29.10.2013 r. \#931 «Pro udoskonalennâ likuval'nogo harčuvannâ ta roboti diêtologičnoï sistemi v Ukraïni» [Order of Ministry of Health from 29.10.2013 № 931 «About the improvement of therapeutic feeding and dietary system in Ukraine»]. Available at: http://zakon4.rada.gov.ua/laws/show/z2205-13 (In Ukrainian).

10. P'âtnic'ka G. T. Formuvannâ strategï rozvitku pidpriêmstv restorannogo gospodarstva [Formation of restaurants enterprises development strategy]. Doctoral Thesis. Kyiv, 2008. Available at: http://tourlib.net/aref_tourism/ pjatnycka.htm (In Ukrainian).

11. Postanova Kabìnetu Mìnistrìv Ukrä̈ni vìd 17 bereznâ 2000 r. \# 521 «Pro Osnovnì naprâmi zabezpečennâ kompleksnogo rozvitku malih monofunkcional'nih mist» [Ordinance of Cabinet of Ministers of Ukraine from 17.03.2000 № 521 «About the main directions to ensure integrated development of small monofunctional cities»]. Available at: http://zakon4.rada.gov.ua/laws/show/521-2000-\%D0\%BF (In Ukrainian). 